\title{
Effects of Polymetallic Ore Occurrences on Mercury Accumulation by Aquatic Biota in River Ecosystems
}

\author{
M. I. Shapovalov ${ }^{a, *}$, V. A. Gremyachikh ${ }^{b}$, and V. T. Komov ${ }^{b}$ \\ ${ }^{a}$ Adyghe State University, Maykop, Russia \\ ${ }^{b}$ Papanin Institute for Biology of Inland Waters, Russian Academy of Sciences, \\ Borok Nekouzskii raion, Yaroslavl oblast, Russia \\ *e-mail: shapmaksim2017@yandex.ru \\ Received April 20, 2020; revised January 13, 2021; accepted January 28, 2021
}

\begin{abstract}
The study represents the data on metal content in the body of stoneflies Perla pallida Guerin-Meneville, 1838 (Plecoptera, Perlidae) and in muscles of the fish family Cyprinidae from the small tributaries of the Belaya River (Republic of Adygea, Northwest Caucasus) with ore mineralization of various metals including mercury. It was found that mercury $(\mathrm{Hg})$ concentrations in stoneflies are corresponds to from the water basins without local $\mathrm{Hg}$ sources. Mercury content in stoneflies depends on season and is more intensive in early ontogenesis in winter than in the warm season. Mercury concentration in $0.01-0.72 \mathrm{mg} / \mathrm{kg} \mathrm{dry}$ weight can cause the pathomorphological changes in the structure of organs and decrease the adaptive potential in competitive population of stoneflies, in general. The $\mathrm{Hg}$ concentration reached $0.09-0.69 \mathrm{mg} / \mathrm{kg}$ in the studied fish species (bleak, gudgeons, and barbels) and was similar to concentrations in stonefly larvae. This can be related with low size-weight parameters of fishes in samples as wells as with similar feeding patterns of hydrobionts.
\end{abstract}

Keywords: mercury, aquatic biota, river ecosystems, ore occurrences in catchment areas

DOI: $10.1134 / \mathrm{S} 199508292105014 \mathrm{X}$

\section{INTRODUCTION}

The global emission of $\mathrm{Hg}$ from natural and anthropogenic sources into the atmosphere, followed by the migration and deposition to the surface of aquatic and terrestrial ecosystems, is still the main reason for the increase in its content and negative impact on biota (Kolka et al., 2011; Eagles-Smith et al., 2016). Various compounds of this metal, including the most toxic and bioavailable methylated mercury, form strong chemical bonds with compounds that make up the tissues of living organisms and accumulate in concentrations hazardous to human health. It has been experimentally revealed that, in vertebrates, high levels of $\mathrm{Hg}$ in tissues lead to chromosomal aberrations and blood pathologies and negatively affect the nervous system and embryonic development of the fetus (Topashka-Ancheva et al., 2003; Scheuhammer, 2007; Tavshunsky et al., 2017). In invertebrates, this relates to deformations of vital structures, the deceleration of larval growth, and processes of metamorphosis and regeneration of damaged organs (Medvedev and Komov, 2005; Gremyachikh et al., 2006; Jensen et al., 2007).

Studies of the dependence of the accumulation of $\mathrm{Hg}$ by living organisms on the parameters of the environment have been and are still carried out mainly in aquatic and near-aquatic ecosystems, where the activity of bacterial methylation is high, contributing to the inclusion of mercury in food webs (Gilmour et al., 2013; Tavshunsky et al., 2017). Elevated concentrations of $\mathrm{Hg}$ in the muscles of fish from rivers and lakes in Russia were recorded both when metal was originated from industrial wastewater (Leonova et al., 2006) and in the absence of local sources in the catchment area, for example, in acidic (water $\mathrm{pH}<5.0$ ) lakes in the northwest of Russia (Haines et al., 1992, 1995; Stepanova and Komov, 1997). The most significant concentrations of $\mathrm{Hg}$ in the lithosphere are found the regions of its deposits and ore occurrences, although they contain only $0.02 \%$ of all mercury (Saukov, 1975). The bulk of $\mathrm{Hg}$ is in the form of compounds in mercury minerals and as isomorphic or mechanical impurities in other minerals and often accompanies metals of the platinum group. Therefore, in the presence of polymetallic and especially mercury ores in the catchment area, the probability of $\mathrm{Hg}$ in the trophic webs of aquatic ecosystems increases.

In the foothill regions of the North Caucasus, in the Belaya River basin, several ore fields with isolated points of ore occurrences of tungsten, polymetallic ores, gold ore and placer gold, mercury, and manganese have been identified (Volkodav, 2012). However, 

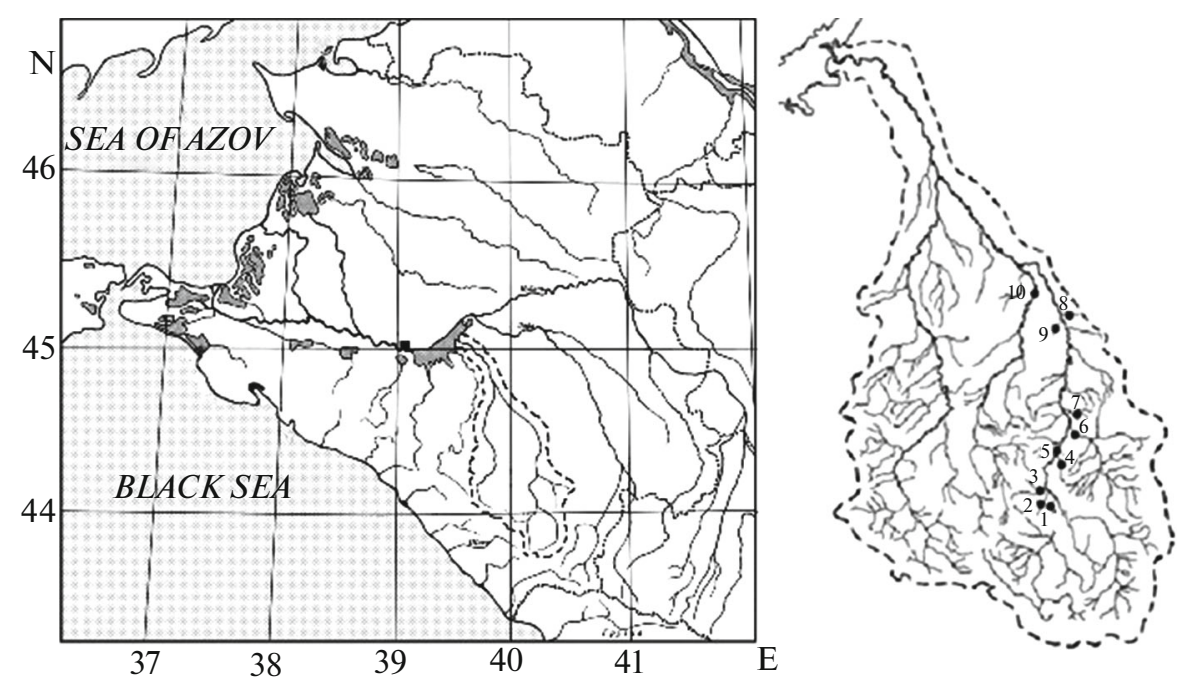

Fig. 1. Locations of sampling stations in the tributaries to the Belaya River (numbering from the river head to mouth): (1) Lipovaya River; (2) Khamyshinka River; (3) Bzykha River; (4) Syuk River; (5) Belaya River, near the settlement of Nikel'; (6) Dakh River, downstream of a bridge; (7) Mishoko River; (8) Maykopskaya River; (9) Shuntuk River; and (10) Kurdzhips River, near the settlement of Krasnyi Most.

studies on the content of mercury in aquatic ecosystems of this region have never been carried out.

The goal of the present paper is to investigate the effect of polymetallic ore outcrops found in the Belaya River catchment area on $\mathrm{Hg}$ accumulation in representatives of amphibiotic invertebrates (Plecoptera larvae) and fish.

\section{MATERIALS AND METHODS}

The Belaya River is the second longest and the most powerful in terms of the discharge volume of the left-bank tributary of the Kuban River, located on the

Table 1. Hydrographic characteristics of small rivers inflowing the Belaya River

\begin{tabular}{l|c|c|c}
\hline \multicolumn{1}{c|}{ River } & $\begin{array}{c}\text { Sampling } \\
\text { station }\end{array}$ & $\begin{array}{c}\text { River } \\
\text { channel } \\
\text { length, km }\end{array}$ & $\begin{array}{c}\text { Height above } \\
\text { sea level } \\
\text { (head/mouth) }\end{array}$ \\
\hline Lipovaya & 1 & 8 & $1340 / 560$ \\
Khamyshinka & 2 & 7 & $1330 / 550$ \\
Bzykha & 3 & 11 & $1710 / 530$ \\
Syuk & 4 & 14 & $990 / 470$ \\
Belaya & 5 & 273 & $2300 / 30$ \\
Dakh & 6 & 27 & - \\
Mishoko & 7 & 9.4 & $890 / 410$ \\
Maykopskaya & 8 & 9.5 & $640 / 280$ \\
Shuntuk & 9 & 12 & $-/ 276$ \\
Kurdzhips & 10 & 100 & $2300 / 224$ \\
\hline
\end{tabular}

A dash indicates no data. border of the western and northwestern parts of the Greater Caucasus in the foothill region of the Republic of Adygea. It originates on the slopes of the FishtOshten mountain range and flows into the Krasnodar Reservoir. The river is $277 \mathrm{~km}$ in length and the catchment area is $5990 \mathrm{~km}^{2}$ (Mel'nikova and Komlev, 2003).

The river basin is a system within which natural, inhabited territories, and agricultural lands interact. The most important components of the natural landscape complexes of the Belaya River basin are small streams which were studied at ten sampling stations (Fig. 1, Table 1).

In the Belaya River basin, the occurrence of ore mineralization of various metals, including $\mathrm{Hg}$, is concentrated. The Khamyshinskoye (Shakhanskoye) mineralization field occupies most of the interfluve of the Bzykha and Khamyshinka rivers and the left tributaries of the Belaya River (sampling stations 1-3) (Volkodav, 2012). Of the five isolated ore occurrences, the highest $\mathrm{Hg}$ content was noted in the Shahanskoye $(0.012 \%-0.2 \%)$. Here, in the transverse vertical cracks, in the veins of other minerals, cinnabar is found in the form of inclusions and deposits, which is often accompanied by native mercury. The $\mathrm{Hg}$ content in other ore occurrences usually does not exceed hundredths of a percent.

The Belorechenskoye ore field is located in the Syuk River valley (sampling station 4), which flows into the Belaya River (sampling station 5) downstream the settlement of Nikel'. The leading ore-forming minerals of the Belorechenskoye barite ore filed are barite, quartz, calcite, and ankerite, while cinnabar is a rare mineral. Mercury mineralization is also con- 
tained in the Triassic strata of the Sakhray River area, a tributary of the Dakh River (sampling station 6) (Pekov et al., 2010). The rest of the stations (7-10), located downstream of the Belaya River, do not have manifestations of ore mineralization of metals within their catchment basins.

The studied rivers are typical small watercourses with rocky bottoms. In the bottom invertebrate communities of the Belaya River and its main tributaries, 238 species of invertebrates have been identified, $87.0 \%$ of which are insects. They are dominated by Caucasian

littoreophilous representatives of zoobenthos: on biotopes with high water-current velocity, EpeorusSimuliidae-Baetis-Blephariceridae; moderate velocity, Ecdyonurus-Baetis-Rhyacophila-HydropsichPerla-Gammarus; and low velocity, Gammarus-Limephilidae (Shapovalov, 2020).

The materials included 326 stonefly larvae Perla pallida Guerin-Meneville, 1838 (Plecoptera, Perlidae), an amphibiotic insect and aquatic organism at the larval stage. In regards to fish, 35 Kuban spirlin Alburnoides kubanicus Bănărescu, 1964; 29 minnow Phoxinus sp.; 9 Caspian gudgeon Gobio cf. holurus Fowler, 1976; and 3 Kuban barbel Barbus kubanicus Berg, 1912. Stonefly larvae were sampled in 2012 and 2013 and fish in 2014 and 2015.

The larvae of stoneflies are widespread in all biotopes of the Belaya River and its tributaries at height of no more than $200 \mathrm{~m}$ above sea level. They dwell in cracks on the underside of stones (avoiding a very fast current) and under large stones, where the layer of loose pebbles lies. Large species of fam. Perlidae have a long period of development in a watercourse (up to 3 years) and an active lifestyle. Stoneflies, like the larvae of other insects, may consume detritus of various origins, mycoflora, unicellular and filamentous algae, tissues of macrophytes, and mosses, as well as all kinds of invertebrates (Monakov, 2003). Representatives of carnivorous stoneflies species, which include Perla pallida, switch to animal food as they grow, feeding primarily on dipteran larvae, whose share of the total number of food components is $68.6-74.3 \%$, and then on larger organisms: caddisflies larvae and mayflies (Shapovalov, 2020). The feeding spectra of stonefly larvae may expand as they grow and develop. Differences in the composition of food are most often determined by the composition of the population of the watercourse in a particular period.

The fish sampled in the tributaries of the Belaya River are rheophylic cyprinids, whose diet includes insect larvae to varying degrees (Troitskii and Tsunikova., 1988; Atlas ..., 2003).

The body length and weight of the sampled animals were measured prior to the processing of samples with further drying at $36^{\circ} \mathrm{C}$ (whole insects were used; in fish, a fragment of dorsal skeletal muscles was dissected). The mercury content was determined in two or three replicates by the atomic absorption method on a RA-915+ mercury analyzer with a PIRO (Lumex) attachment without preliminary sample preparation. The accuracy of analytical measurement methods was controlled using DORM-2 and DOLM-2 certified biological material (Institute of Environmental Chemistry, Ottawa, Canada).

Data on $\mathrm{Hg}$ concentrations are presented as mean values and their errors $(x \pm m x)$ with min-max. Since the distribution of the data differed from the normal (Shapiro-Wilk test), the nonparametric Spearman test was used to identify correlations between the studied indicators, and the Kruskal-Wallis median was used to assess the significance of differences between the samples (the differences are significant at $p<0.05$ ) (Sokal and Rohlf, 1995).

\section{RESULTS}

The body length and weight of stonefly larvae varied widely: length $5.0-32.0 \mathrm{~mm}$ and weight $7.0-455.0 \mathrm{mg}$. The minimal and maximal concentrations of $\mathrm{Hg}$ in the body of insects reached 0.01 and 0.72 , respectively; on average, over watercourses, it was $0.06-0.38 \mathrm{mg}$ $\mathrm{Hg} / \mathrm{kg}$ dry weight (Table 2). The metal content in animals sampled the closest to the source and located in the zone of ore occurrences at sampling station 1 was statistically significantly higher (Fig. 2). The accumulation of $\mathrm{Hg}$ by stoneflies at sampling station 2 exceeded that at sampling stations $3-5,7$, and 10; at sampling station 6 , it exceeded that at sampling stations 4 and 5. For samples from sampling stations 1, 2, 4, 6, and 10, a significant negative relationship between $\mathrm{Hg}$ concentrations in larvae and their body weight was noted: $r_{s}=(-0.56)-(-0.78)$ at $p<0.05$; for samples from sampling stations $2,4,6$, and 10 , it was also with body length, $r_{s}=(-0.55)-(-0.72)$ at $p<0.05$.

The entire group sample was divided into two subgroups: the first included animals from watercourses located in areas of ore occurrence (sampling stations 16); the second, from watercourses without ore occurrence in the catchment (sampling stations 7-10; at station 9, only fish). The metal concentrations in stoneflies from the first group were statistically significantly higher (Kruskal-Wallis test, $H=21.6, p<$ 0.000 ) than from the second: $0.15 \pm 0.01$ and $0.07 \pm$ $0.004 \mathrm{mg} / \mathrm{kg}$ dry weight, respectively. The body length and body weight of the larvae of the first group were significantly less than those of the second group: $17.5 \pm 0.3 \mathrm{~mm}$ and $19.1 \pm 0.6 \mathrm{~mm}(H=5.9, p<0.02)$ and $125.3 \pm 6.0 \mathrm{mg}$ and $168.0 \pm 13.2 \mathrm{mg}(H=13.9, p<$ $0.002)$. With an increase in body length $(L)$, they less intensively gained body weight $(W)$ : in the larvae of the first group, $W=-158.56+16.18 \mathrm{~L}$ and, in the second, $W=-228.52+20.75 L$

In stoneflies from the first group, the same statistically significant negative relationship between the 
Table 2. Content of mercury in stoneflies larvae from the tributaries to the Belaya River

\begin{tabular}{|c|c|c|c|c|c|}
\hline $\begin{array}{c}\text { Number of } \\
\text { sampling station }\end{array}$ & Data & $n$ & $\begin{array}{l}\text { Body length, } \\
\text { mm }\end{array}$ & Body weight, mg & $\begin{array}{l}\mathrm{Hg}, \mathrm{mg} / \mathrm{kg} \\
\text { dry weight }\end{array}$ \\
\hline 1 & April, 2012 & 25 & $\frac{15.9 \pm 0.9}{9.0-27.5}$ & $\frac{96.7 \pm 16.3}{16.0-325.5}$ & $\frac{0.38 \pm 0.03}{0.17-0.72}$ \\
\hline & May 4, 2013 & 20 & $\frac{19.4 \pm 1.4}{10.0-29.8}$ & $\frac{166.7 \pm 28.3}{19.0-403.0}$ & $\frac{0.24 \pm 0.02}{0.14-0.42}$ \\
\hline & June 19, 2013 & 19 & $\frac{13.5 \pm 1.5}{7.8-31.2}$ & $\frac{84.2 \pm 28.2}{15.0-455.0}$ & $\frac{0.26 \pm 0.02}{0.12-0.38}$ \\
\hline & & & \multicolumn{3}{|c|}{ Mean } \\
\hline Total for station 1 & $2012-2013$ & 64 & $\frac{16.3 \pm 0.8}{7.8-31.2}$ & $\frac{114.9 \pm 14.2}{15.0-455.0}$ & $\frac{0.31 \pm 0.02}{0.12-0.72}$ \\
\hline 2 & May 4, 2013 & 43 & $\frac{21.5 \pm 0.6}{15.0-32.0}$ & $\frac{185.2 \pm 14.0}{69.0-450.0}$ & $\frac{0.11 \pm 0.02}{0.05-0.55}$ \\
\hline & June 19, 2013 & 28 & $\frac{18.3 \pm 1.0}{10.8-29.0}$ & $\frac{136.1 \pm 19.7}{26.0-396.0}$ & $\frac{0.15 \pm 0.01}{0.07-0.22}$ \\
\hline & & & \multicolumn{3}{|c|}{ Mean } \\
\hline Total for station 2 & 2013 & 71 & $\frac{20.3 \pm 0.6}{10.8-32.0}$ & $\frac{165.8 \pm 11.8}{26.0-450.0}$ & $\frac{0.13 \pm 0.01}{0.05-0.55}$ \\
\hline 3 & May 4, 2013 & 11 & $\frac{23.1 \pm 1.0}{18.0-28.6}$ & $\frac{192.4 \pm 21.9}{97.0-314.0}$ & $\frac{0.06 \pm 0.006}{0.03-0.11}$ \\
\hline 4 & June 19, 2013 & 39 & $\frac{18.2 \pm 0.9}{8.0-28.1}$ & $\frac{139.5 \pm 16.6}{17.0-376.0}$ & $\frac{0.06 \pm 0.003}{0.03-0.11}$ \\
\hline 5 & October 2012 & 33 & $\frac{12.1 \pm 0.5}{5.0-22.5}$ & $\frac{54.5 \pm 6.3}{7.0-212.0}$ & $\frac{0.07 \pm 0.006}{0.02-0.17}$ \\
\hline 6 & October 2012 & 32 & $\frac{15.7 \pm 0.5}{10.0-21.0}$ & $\frac{77.2 \pm 6.1}{19.0-163.0}$ & $\frac{0.14 \pm 0.005}{0.08-0.19}$ \\
\hline & May 4, 2013 & 20 & $\frac{19.5 \pm 1.0}{13.0-28.2}$ & $\frac{144.0 \pm 21.2}{42.0-363.0}$ & $\frac{0.06 \pm 0.006}{0.03-0.10}$ \\
\hline & & & \multicolumn{3}{|c|}{ Mean } \\
\hline Total for station 6 & $2012-2013$ & 52 & $\frac{17.2 \pm 0.5}{10.6-28.2}$ & $\frac{102.9 \pm 9.9}{19.0-363.0}$ & $\frac{0.11 \pm 0.01}{0.03-0.19}$ \\
\hline 7 & May 2013 & 15 & $\frac{16.5 \pm 1.2}{8.0-24.0}$ & $\frac{136.0 \pm 25.5}{18.0-368.0}$ & $\frac{0.06 \pm 0.01}{0.01-0.09}$ \\
\hline 8 & May 18, 2013 & 26 & $\frac{19.9 \pm 0.7}{13.0-30.5}$ & $\frac{179.7 \pm 19.6}{39.0-451.0}$ & $\frac{0.09 \pm 0.01}{0.02-0.16}$ \\
\hline 10 & July 3, 2013 & 15 & $\frac{20.3 \pm 1.2}{12.2-28.0}$ & $\frac{179.8 \pm 24.8}{52.0-330.0}$ & $\frac{0.07 \pm 0.006}{0.04-0.13}$ \\
\hline & & & \multicolumn{3}{|c|}{ Mean } \\
\hline $\begin{array}{l}\text { Total for all sta- } \\
\text { tions }\end{array}$ & $2012-2013$ & 326 & $\frac{17.8 \pm 0.3}{5.0-32.0}$ & $\frac{132.6 \pm 5.5}{7.0-455.0}$ & $\frac{0.13 \pm 0.01}{0.01-0.72}$ \\
\hline
\end{tabular}

Here and in Table 3: top is the mean and error of mean; bottom is the min-max, and $n$ is the number of analyzed stonefly larvae; numbers of sampling stations are the same as in Fig. 1. 


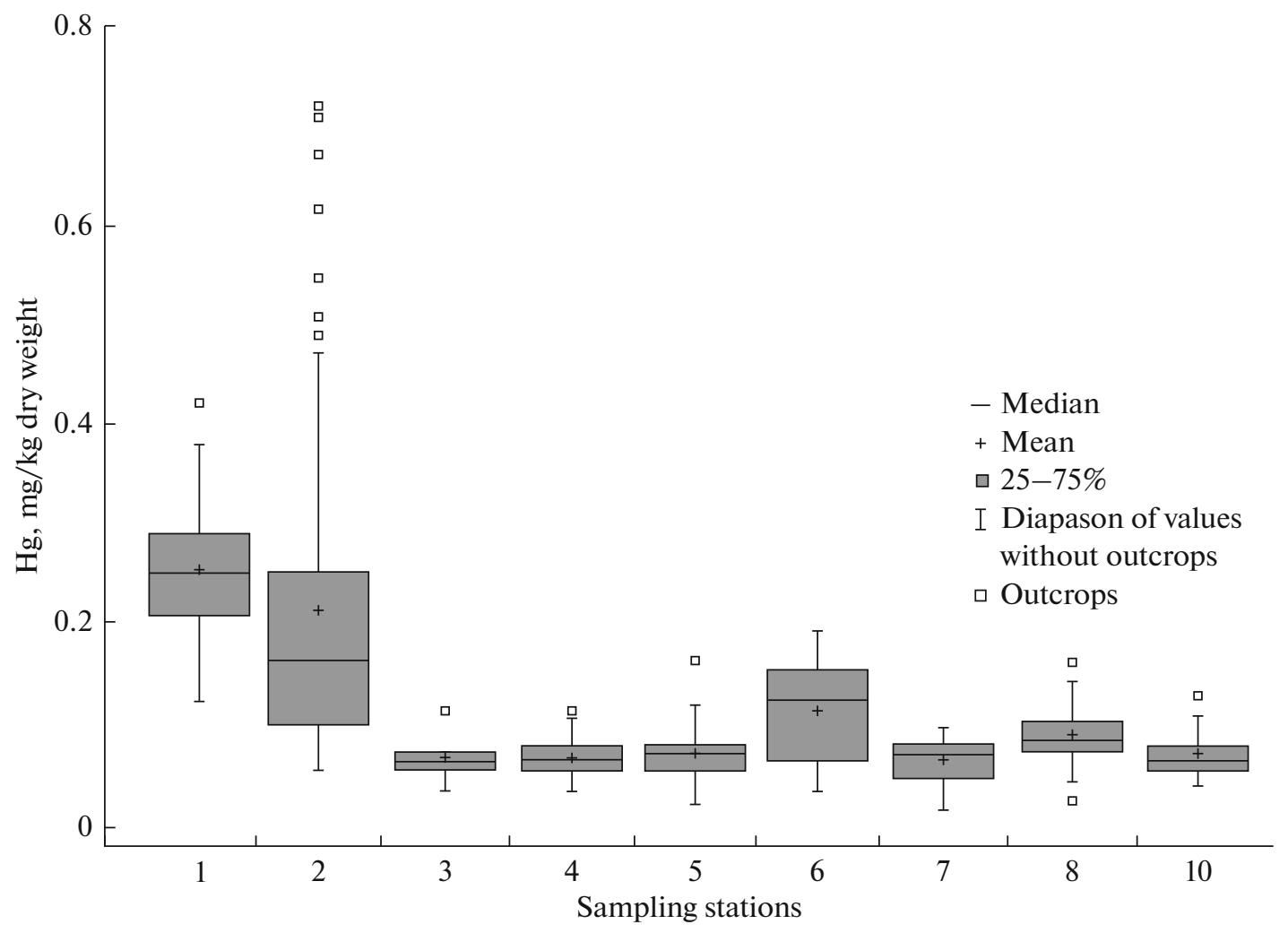

Fig. 2. Mercury content in stonefly larvae at sampling stations located in the ore occurrence zone (sampling stations $1-6)$ and outside it (sampling stations 7, 8, and 10).

mercury content and length and weight was revealed: $r_{\mathrm{s}}=-0.24, p<0.05$. In stoneflies from the second group, the decrease in metal concentration with the growth of animals is also significant, but less pronounced: with length $r_{\mathrm{s}}=-0.17, p<0.05$, weight $r_{\mathrm{s}}=$ $-0.11, p<0.05$. A seasonal (from spring to autumn) decrease in the average length and weight of stonefly larvae (in both cases, $r_{\mathrm{s}}=-0.38, p<0.05$ ) was noted at a relatively stable level. accumulation of $\mathrm{Hg}$. In two groups of different sizes (in the first, the length of stoneflies is $\leq 15 \mathrm{~mm}$ and, in the second, $>15 \mathrm{~mm}$ ) sampled in the tributaries of the mineralization zone, spring individuals were significantly larger than summer-autumn ones. In the first group (smaller individuals), the metal content decreased from spring to autumn and, in the second, it did not change significantly (Fig. 4).

The minimal and maximal concentrations of $\mathrm{Hg}$ in the muscles of the studied fish species varied within $0.09-0.69 \mathrm{mg} / \mathrm{kg}$ dry weight (Table 3, Fig. 5). The metal content in the muscles of the minnow is statistically significantly higher than that of the Kuban spirlin. The accumulation of mercury by minnows at sampling stations 1 and 2 did not differ; in the spirlin at sampling station 9, it was higher than that of fish at sampling stations 2 and 10 . The same concerns the fish body weight. A significant positive relationship between $\mathrm{Hg}$ concentrations in muscles and fish body weight was noted for the spirlin: $r_{\mathrm{s}}=0.53$ at $p<0.05$. The content of metal in the muscles of the spirlin from the stations located in the ore occurrence zones and outside them did not differ statistically significantly.

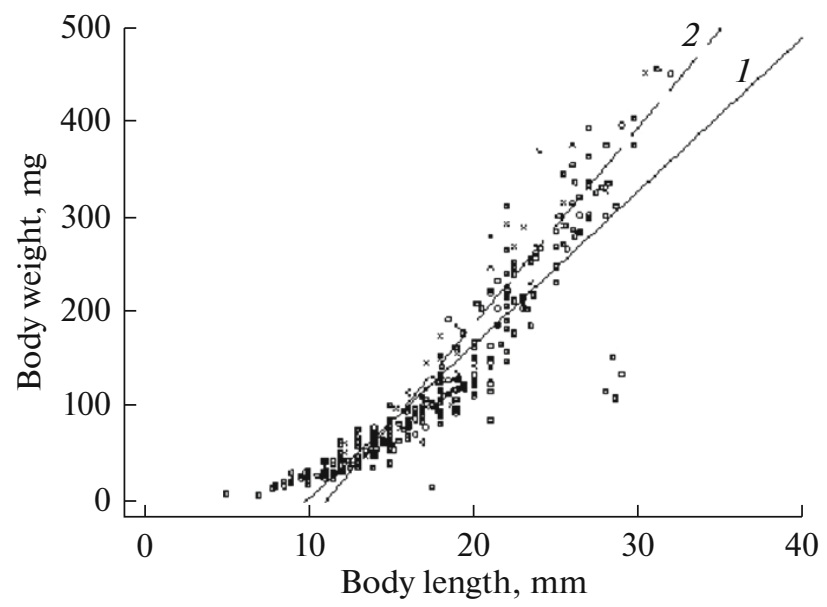

Fig. 3. Correlation between body length and weight at sampling stations located in the ore occurrence zone (1) and outside it (2). 

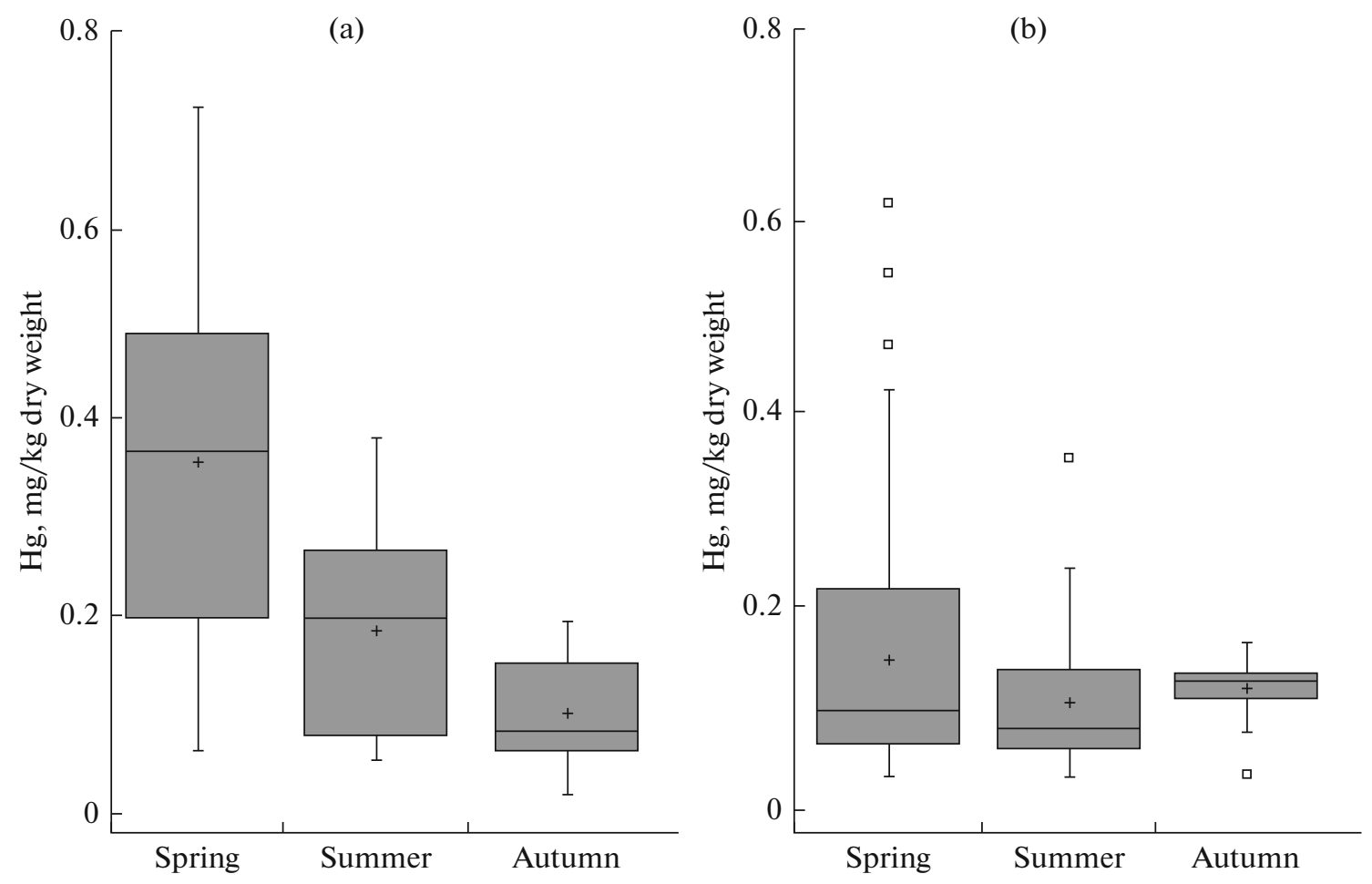

Fig. 4. Seasonal changes in $\mathrm{Hg}$ content in stonefly larvae $\leq 15 \mathrm{~mm}$ in length (a) and $>15 \mathrm{~mm}$ (b) sampled in tributaries in the ore occurrence zone.

\section{DISCUSSION}

The input of $\mathrm{Hg}$ from catchment areas with outcrops of polymetallic ore occurrences into waterbodies and streams is both of a natural and anthropogenic nature. In the first case, this is due to natural processes and, in the second, with the more rapid erosion of mineralization zones as a result of human economic activities for the extraction, preliminary processing of minerals, and storage and disposal of waste dumps at their enrichment (Kocman et al., 2011; Hsu-Kim et al., 2018). According to recent estimates, artisanal and small-scale industrial gold mining may be significant sources of $\mathrm{Hg}$ for freshwater ecosystems (880 t/year), both industrial production and wastewater emissions (220 t/year); the mobilization of land resources; and changes in land use, forestry, and frequency and intensity of wildfires (170-300 t/year) (Obrist et al., 2018).

The Belaya River basin in the upstream reaches is located in the zone of gold-bearing, copper and leadzinc mineralization interspersed with mercury-bearing minerals (in particular, cinnabar and native $\mathrm{Hg}$ ) (Volkodav, 2012). The development of the Belaya River gold placers began in 1932 and continued until 1941, although prospecting works in 1934 and 1935 did not reveal new placers on the river or industrial mineralization (Volkodav, 2012).

The small valleys of the Belaya River Basin were developed by prospectors at the beginning of the last century and continue to interest local metal miners to this day. Any economic activity in the catchment of rivers (mining of polymetallic ores, deforestation, and

regulation of watercourses) may lead to an increase in the removal of finely dispersed suspension of mercury mineral cinnabar and the accumulation of mercury in bottom sediments within slowly flowing river sections (Hsu-Kim et al., 2018).

The metal content in the larvae of stoneflies and muscles of the studied fish species from the Belaya River and its tributaries in the zone of ore fields and outside it is comparable to that revealed in larvae of amphibiontic insects and fish from waterbodies and watercourses of various regions lacking local sources of pollution in the catchment area and predominantly prone to atmospheric pollution. Thus, the concentration of total $\mathrm{Hg}$ in chironomid larvae from lakes in the Canadian Arctic varies within $0.09-0.50 \mathrm{mg} / \mathrm{kg}$ dry weight (Ganter et al., 2010). In larvae of dragonflies from subtropical freshwater Lake Caddo (Texas and Louisiana, United States), it is 0.17-0.31 (Chumchal et al., 2011); in Losha River (Vologda oblast), Savala River (Voronezh oblast), and an artificially dug channel opening in Rybinsk Reservoir and Sunozhka River (Yaroslavl oblast), it is $0.02-0.07,0.04-0.15$, and $0.01-0.38 \mathrm{mg} / \mathrm{kg}$ dry weight, respectively (Gremyachikh et al., 2013).

The seasonal decrease in the body length and weight of larvae of Perla pallida Guerin-Meneville, 1838 is due to the fact that in the spring samples a sig- 
nificant part of the animals is represented by large overwintered specimens (the development cycle in stoneflies from Adygean watercourses is about 3 years). Later samples contain individuals hatched in spring (much less often in summer and autumn) at early stages of development (Cherchesova and Zhiltsova, 2013). Low concentrations of $\mathrm{Hg}$ in summer and autumn larvae in the small-sized group are associated with seasonal changes in the composition of food: at a specific time period, animals choose the most numerous and available food items (Monakov, 2003). In winter and early spring, it is mainly detritus and bacteria that have developed in and on it; from late spring to autumn, it is algae and invertebrates. According to de Wit et al. (2012), the consumption with food of the bacteria transforming inorganic forms of mercury into organometallic ones more efficiently than algae explains the increased metal content in aquatic organisms in the winter-spring period. In addition, overwintering larvae do not molt, and each molt during the growing season is accompanied by rapid growth and, accordingly, dilution of the accumulated $\mathrm{Hg}$ (Ross et al., 1985). In large larvae of stoneflies, the metal content does not change significantly with the change of seasons due to obligate zoophagy: detritus and algae enter the stomachs of predators from the intestines of eaten prey (Monakov, 2003).

Fish with both low and increased concentrations of metal in muscles are found in the rivers and lakes of nature reserves in European Russia remote from sources of $\mathrm{Hg}$ emissions, which is determined by the biogeochemical (ecological) characteristics of the waterbodies and their drainage basins. In perch from the Usman River (the Voronezhsky Nature Reserve), a content of $0.35-1.30 \mathrm{mg} / \mathrm{kg}$ dry weight was recorded; in the lakes of the Rdeisky Nature Reserve, 0.20-12.00 (Komov et al., 2009); in Darvinsky Reserve, 0.10-4.95 (Stepanova and Komov, 1997); and in Oksky Reserve, $0.10-2.50 \mathrm{mg} / \mathrm{kg}$ dry weight (Gremyachikh et al., 2012).

Unlike stoneflies, the levels of metal in the muscles of the Kuban spirlin from the Belaya River and its tributaries located closer to the river head in the zone of ore fields (sampling station 2) and outside it (sampling stations 7, 8, and 10) are low, but upon approaching the mouth of the river, these values, on the contrary, increase. However, this is determined by the small size of fish caught in the upper reaches: for many species, a correlation was noted between the size and content of mercury in the internal organs and muscle tissue (Komov et al., 2009; Gremyachikh et al., 2012). The metal content in the muscles of predatory fish from the Tapajos River (Brazil), one of the main tributaries of the Amazon, from the mid-1980s, where traditional gold mining takes place, reaches $20 \mathrm{mg} / \mathrm{kg}$ dry matter (Nevado et al., 2010). With an increase in the distance from the mining sites downstream of the river, it decreases, as is observed in the Katun and Selenga rivers with numerous mineralization zones in the catch-
Table 3. Content of mercury in the muscle tissues of fish the Belaya River tributaries

\begin{tabular}{|c|c|c|c|}
\hline $\begin{array}{c}\text { Number } \\
\text { of sampling station }\end{array}$ & $n$ & $\begin{array}{l}\text { Fish body } \\
\text { weight, } g\end{array}$ & $\begin{array}{l}\mathrm{Hg}, \mathrm{mg} / \mathrm{kg} \\
\text { dry weight }\end{array}$ \\
\hline \multirow[b]{2}{*}{2} & \multicolumn{3}{|c|}{ Kuban spirlin } \\
\hline & 6 & $\frac{0.11 \pm 0.02}{0.06-0.17}$ & $\frac{0.15 \pm 0.005}{0.15-0.18}$ \\
\hline 8 & 7 & $\frac{3.1 \pm 0.7}{1.6-6.6}$ & $\frac{0.26 \pm 0.03}{0.13-0.34}$ \\
\hline 9 & 6 & $\frac{5.1 \pm 1.1}{2.9-8.9}$ & $\frac{0.51 \pm 0.07}{0.26-0.69}$ \\
\hline 10 & 16 & $\frac{3.2 \pm 0.7}{0.8-13.4}$ & $\frac{0.16 \pm 0.01}{0.09-0.30}$ \\
\hline \multirow[t]{2}{*}{ Mean } & & $\frac{3.0 \pm 0.5}{0.06-13.4}$ & $\frac{0.24 \pm 0.03}{0.09-0.69}$ \\
\hline & \multicolumn{3}{|c|}{ Minnow } \\
\hline 1 & 14 & $\frac{0.03 \pm 0.007}{0.02-0.15}$ & $\frac{0.27 \pm 0.02}{0.16-0.40}$ \\
\hline \multirow{3}{*}{ Mean } & \multirow[t]{2}{*}{15} & $\frac{0.11 \pm 0.009}{0.07-0.18}$ & $\frac{0.25 \pm 0.01}{0.17-0.40}$ \\
\hline & & $\frac{0.07 \pm 0.01}{0.02-0.18}$ & $\frac{0.26 \pm 0.01}{0.16-0.40}$ \\
\hline & \multirow{3}{*}{5} & \multicolumn{2}{|c|}{ Gudgeon } \\
\hline \multirow[t]{2}{*}{9} & & $\frac{1.6 \pm 0.7}{0.4-4.2}$ & $\frac{0.20 \pm 0.02}{0.12-0.24}$ \\
\hline & & Kuban bar & \\
\hline 9 & 3 & $\frac{2.0 \pm 0.8}{0.8-3.6}$ & $\frac{0.19 \pm 0.02}{0.15-0.23}$ \\
\hline
\end{tabular}

ment area (Vasil'ev and Sukhenko, 1993; Komov et al., 2014), in which the concentrations of $\mathrm{Hg}$ in fish vary in the range of $0.25-0.55$ and $0.24-2.33 \mathrm{mg} / \mathrm{kg}$ dry weight, respectively.

In water, $\mathrm{Hg}$ is present in small amounts in a mixture of various forms: mainly suspended and colloidal particles and, to a lesser extent, a true solution (Han and Gill, 2005; Hsu-Kim and Sedlak, 2005; Balogh et al., 2008; Schuster et al., 2008; Dittman et al., 2010). In a study conducted on the Idrijetsa River (Slovenia), draining the territory of the former mercury mine, it was found that $\mathrm{Hg}$ is in the form of a finely suspended material, including colloids, and mercury is transported downstream during short but extreme hydrometeorological events when the metal is remobilized from the bottom sediments of the river (Kocman et al., 2011). During such events, the concentrations of $\mathrm{Hg}$ in water and bottom sediments rapidly decrease and, at the same time, bacterial methylation of the metal occurs, which increases the propor- 


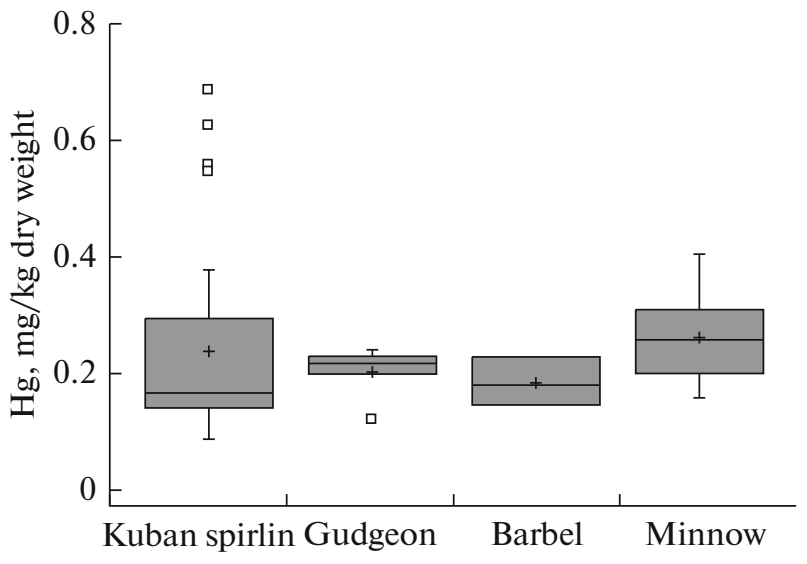

Fig. 5. Mercury content in the muscles of fish sampled in Belaya River watercourses.

tion of methylmercury $(\mathrm{MeHg})$ in the total $\mathrm{Hg}$ content and, consequently, the risk of accumulation in biota (Ullrich et al., 2007; Kocman et al., 2011; Jackson et al., 2019).

The bioavailability of $\mathrm{Hg}$ for biota depends in a complex nonlinear manner on a variety of biological and ecological factors that affect the patterns and pathways of metal migration along food webs (Lavoie et al., 2013; Karimi et al., 2016; Polito et al., 2016; Eagles-Smith et al., 2018; Hsu-Kim et al., 2018). This is why bottom sediments of waterbodies and soils in the catchment areas containing relatively high $\mathrm{Hg}$ concentrations with low bioavailability of metal may be sources of its accumulation in aquatic organisms only to low levels. For instance, in the muscles of bream from Lake Serebry located in the immediate vicinity of the Karabash copper-smelting plant in Chelyabinsk oblast, $\mathrm{Hg}$ concentrations are several times lower than in the muscles of bream from Lake Seliger in Tver oblast, in the vicinity of which there is practically no industry (Tatsii et al., 2017).

Since the second half of the last century, there has been no active industrial and artisanal mining of gold or polymetallic ores in the Belaya River basin. This is why the input of $\mathrm{Hg}$ occurs mainly with atmospheric precipitation and runoff from the river catchment area as a result of the erosion (leaching) of rocks, as well as of mountain, floodplain-meadow, and forest soils (Volkodav, 2012). The specificity of the river hydrological regime (closer to the source, glacial, snow and storm water supply the sections closer to river headwaters; there is a high water-current velocity) does not create favorable conditions for the bacterial methylation of mercury compounds increasing its bioavailability in either the water column or in bottom sediments. The accumulation of $\mathrm{Hg}$ by animals depends on many environmental factors: the water $\mathrm{pH}$ level, the area of wetlands in the drainage basin, and the concentration of dissolved organic matter (Harding et al., 2006). However, the main mechanism for an increase in the concentration of metal in each subsequent link is its trophic transport along the food web (Eagles-Smith et al., 2018).

The predatory larvae of stoneflies participate in the transfer of $\mathrm{Hg}$ along the food web of aquatic ecosystems as secondary and tertiary consumers, which are at the same trophic level with some fish and at the same time are a food object for omnivorous and predatory fish species. In the bottom fauna of mountain streams, amphibiontic insects are one of the most abundant and widespread groups of invertebrates. Potential food items for predatory stonefly larvae are $>40 \%$ of the species composition of benthic invertebrates in the studied rivers (Shapovalov, 2011, 2020). By consuming large insect larvae (in a specific case, dragonflies), fish in the watercourse limit the $\mathrm{Hg}$ flux into the terrestrial ecosystem, but do not affect the mercury flux passing through the small larvae of chironomids and caddis flies (Tweedy et al., 2013).

The present study revealed that concentrations of $\mathrm{Hg}$ in larvae of stoneflies and muscles of fish from the small streams of Adygea are low and comparable to each other: $0.01-0.72$ and $0.09-0.69 \mathrm{mg} / \mathrm{kg}$ dry weight, respectively, which may be associated with the low size and mass parameters of fish in the samples and, as a result, the similarity of the food spectra of the aquatic organisms under study. As food items, the larvae of stoneflies (and also adults, even taking into account the possible increase in metal concentration as a result of metamorphosis), accumulating $\mathrm{Hg}$ within the established values, cannot significantly harm the predatory representatives of the aquatic, near-water, and terrestrial ecosystems in the Belaya River basin.

As was shown on the chironomids from Arctic lakes, during metamorphosis, the concentration of methylated forms of mercury increases two- to threefold (Chetelat et al., 2008). Insect imagoes emerging from waterbodies contribute to the removal of metal water and its transfer into terrestrial ecosystems (Speir et al., 2014; Chumchal and Drenner, 2015; Williams et al., 2017) and, at the same time, pose a threat to representatives of the arachno- and avifauna, both nearwater and those unconnected to aquatic ecosystems (Cristol et al., 2008).

$\mathrm{Can} \mathrm{Hg}$ at the recorded concentrations be harmful for the species under study and representatives of nearwater biota? The few experimental and field studies evaluating the potential toxicity of $\mathrm{Hg}$ have been done on a dose-response basis. The concentrations of metal in the medium (water, bottom sediments, and substrate) was revealed to cause lethal (mortality, \% for a certain number of hours), sublethal (slowing growth, motor and respiratory activity, metamorphosis, reproduction, and having a teratogenic effect), and an absence of visible effects of the reaction of living organisms. Thus, the exposure of Chironomus riparius 
Meigen, 1804 larvae to a solution of $\mathrm{Hg}$ chloride $(1.58 \mathrm{mg} / \mathrm{L})$ resulted in the immobilization of $50 \%$ of the individuals after $48 \mathrm{~h}$ (Rodrigues et al., 2013); keeping these larvae on bottom sediments with total $\mathrm{Hg}$ concentrations of $0.93,2.42$, and $3.84 \mathrm{mg} / \mathrm{kg}$ dry weight leads to a decrease in the survival rate of chironomids $(88,80$, and $26 \%$, respectively) and a suppression of growth and development rate compared to control (the percentage of individuals hatched from eggs is 94, 74, and 8\%, respectively) (Chibunda, 2009).

However, it is preferable to judge the danger of $\mathrm{Hg}$ for biota (a set of negative deviations in the development and functioning of biological systems of all levels) by the concentrations of its inorganic and organic forms not in abiotic components of the environment, but in living beings of different levels of the food web, which reflect the features of biogeochemical transformations of metal in specific ecosystem conditions (Jain et al., 2007). In C. riparius larvae reared on mercury-containing food or bottom sediments, the accumulation of $0.6-0.8 \mathrm{mg} \mathrm{Hg} / \mathrm{kg}$ dry weight slows down the metamorphosis, and the proportion of individuals with deformations of the mouth structures of the head capsule increases to $19-20 \%$ (Gremyachikh et al., 2006; Tomilina and Grebenyuk, 2019). The concentrations of $\mathrm{Hg}(0.01-0.72 \mathrm{mg} / \mathrm{kg}$ dry weight) revealed in the larvae of stoneflies, like in chironomids belonging to the group of amphibiotic insects, may lead to pathomorphological deviations in the formation of vital structures and, accordingly, to a decrease in the competitiveness of animals for food resource, increasing their availability to predators.

\section{CONCLUSIONS}

Mercury concentrations in stoneflies from small tributaries of the Belaya River are comparable to those in amphibiontic insects from waterbodies and streams lacking local sources of $\mathrm{Hg}$ in the catchment area and predominantly subject to atmospheric pollution. Higher levels of metal accumulation were found in the larvae of stoneflies from watercourses in the Khamyshinsky field of mineralization (sampling stations 1 and 2), the runoff from which represents an additional, albeit insignificant, source of metal input into the ecosystems of watercourses. The four fish species studied (small specimens predominated in the samples) accumulated $\mathrm{Hg}$ in the same concentrations as the stoneflies. The predatory and large larvae of the stoneflies are not so much food items for small fish as their food competitors. In stoneflies accumulating mercury at concentrations of $0.01-0.72 \mathrm{mg} / \mathrm{kg}$ dry weight, an increase in the proportion of individuals with pathomorphological deviations in the structure of the oral apparatus is possible, leading to a decrease in the viability of the population and, accordingly, the provision of food for animals of higher trophic levels.

\section{FUNDING}

This study was carried out as part of State Task "Physiological, Biochemical, And Immunological Reactions of Aquatic Organisms under the Influence of Biotic and Abiotic Environmental Factors," no. AAAA-A18118012690123-4.

\section{OPEN ACCESS}

This article is licensed under a Creative Commons Attribution 4.0 International License, which permits use, sharing, adaptation, distribution and reproduction in any medium or format, as long as you give appropriate credit to the original author(s) and the source, provide a link to the Creative Commons license, and indicate if changes were made. The images or other third party material in this article are included in the article's Creative Commons license, unless indicated otherwise in a credit line to the material. If material is not included in the article's Creative Commons license and your intended use is not permitted by statutory regulation or exceeds the permitted use, you will need to obtain permission directly from the copyright holder. To view a copy of this license, visit http://creativecommons.org/licenses/by/4.0/.

\section{COMPLIANCE WITH ETHICAL STANDARDS}

Conflict of interests. The authors declare that they have no conflicts of interest.

Statement on the welfare of humans or animals. All applicable international, national, and/or institutional guidelines for the care and use of animals were followed.

\section{REFERENCES}

Atlas presnovodnykh ryb Rossii (Atlas of Freshwater Fishes of Russia), Moscow: Nauka, 2003, vol. 1.

Balogh, S.J., Swain, E.B., and Nollet, Y.H., Characteristics of mercury speciation in Minnesota rivers and streams, Environ. Pollut., 2008, vol. 154, p. 3.

https://doi.org/10.1016/j.envpol.2007.11.014

Cherchesova, S.K. and Zhiltsova, L.A., Opredelitel' vesnyanok (Plecoptera) Kavkaza (Key to the Caucasian Stoneflies (Plecoptera)), Moscow: Mosk. S.-Kh. Akad. im. K.A. Timiryazeva, 2013.

Chetelat, J., Amyot, M., Cloutier, L., and Poulain, A., Metamorphosis in chironomids, more than mercury supply, controls methylmercury transfer to fish in high Arctic lakes, Environ. Sci. Technol., 2008, vol. 42, no. 24, p. 9110. https://doi.org/10.1021/es801619h

Chibunda, R.T., Chronic toxicity of mercury $\left(\mathrm{HgCl}_{2}\right)$ to the benthic midge Chironomus riparius, Int. J. Environ. Res., 2009 , vol. 3 , no. 3 , p. 455 .

https://doi.org/10.22059/IJER.2010.99

Chumchal, M.M. and Drenner, R.W., An environmental problem hidden in plain sight? Small human-made ponds, emergent insects, and mercury contamination of biota in the great plains, Environ. Toxicol. Chem., 2015, vol. 34, no. 6, p. 1197.

https://doi.org/10.1002/etc.2954 
Chumchal, M.M., Rainwater, T.R., Osborn, S.C., et al., Mercury speciation and biomagnification in the food web of Caddo Lake, Texas and Louisiana, USA, a subtropical freshwater ecosystem, Environ. Toxicol. Chem., vol. 30, no. 5 , p. 1153 .

https://doi.org/10.1002/etc.477

Cristol, D.A., Brasso, R.L., Condon, A.M., et al., The movement of aquatic mercury through terrestrial food webs, Science, 2008, vol. 320, p. 335.

https://doi.org/10.1126/science.1154082

Dittman, J.A., Shanley, J.B., Driscoll, C.T., et al., Mercury dynamics in relation to dissolved organic carbon concentration and quality during high flow events in three northeastern U.S. streams, Water Res., 2010, vol. 46, p. W07522. https://doi.org/10.1029/2009WR008351

Eagles-Smith, C.A., Wiener, J.G., Eckley, C.S., et al., Mercury in western north america: a synthesis of environmental contamination, fluxes, bioaccumulation, and risk to fish and wildlife, Sci. Total Environ., 2016, vol. 568, p. 1213. https://doi.org/10.1016/j.scitotenv.2016.05.094

Eagles-Smith, C.A., Silbergeld, E.K., Basu, N., et al., Modulators of mercury risk to wildlife and humans in the context of rapid global change, Ambio, 2018, vol. 47, no. 2, p. 170.

https://doi.org/10.1007/s13280-017-1011-X

Ganter, N., Power, M., Iqaluk, D., et al., Mercury concentrations in landlocked arctic char (salvelinus alpines) from the Canadian Arctic. Part I: Insights from trophic relationships in 18 laces, Environ. Toxicol. Chem., vol. 29, no. 3, p. 621 .

https://doi.org/10.1002/etc.95

Gilmour, C.C., Podar, M., Bullock, A.L., et al., Mercury methylation by novel microorganisms from new environments, Environ. Sci. Technol., 2013, vol. 47, p. 11810.

https://doi.org/10.1021/es403075t

Gremyachikh, V.A., Grebenyuk, L.P., Komov, V.T., and Stepanova, I.K., Accumulation of mercury and its teratogenic effect on larvae of Chironomus riparius Meigen (Diptera: Chironomidae), Biol. Vnutr. Vod, 2006, no. 1, p. 99.

Gremyachikh, V.A., Komov, V.T., Ivanchev, V.P., et al., The content of mercury in the fish muscles of the Oka Nature Reserve and surrounding areas, Tr. Okskogo Gos. Prir. Biosfern. Zapov., 2012, no. 27, p. 377.

Gremyachikh, V.A., Komov, V.T., Trankvilevskii, D.V., et al., The content of mercury in aquatic and amphibiotic insects of various reservoirs and watercourses of the European part of Russia, Materialy V Vserossiiskogo simpoziuma po amfibioticheskim $i$ vodnym nasekomym Gidroentomologiya $v$ Rossii i sopredel'nykh stranakh (Proc. V All-Russia Symp. on Amphibiotic and Aquatic Insects "Hydroentomology in Russia and Adjacent Countries”), Borok, 2013, p. 46.

Haines, T.A., Komov, V.T., and Jagoe, C.H., Lake acidity and mercury content of fish in Darwin National Reserve, Russia, Environ. Pollut., 1992, vol. 78, p. 107. https://doi.org/10.1016/0269-7491(92)90017-5

Haines, T.A., Komov, V.T., Matey, V.E., and Jagoe, C.H., Perch mercury content is related to acidity and color of 26 Russian lakes, Water Air Soil Pollut., 1995, vol. 85, p. 823.

Han, S. and Gill, G.A., Determination of mercury complexation in coastal and estuarine waters using competitive ligand exchange method, Environ. Sci. Technol., 2005, vol. 39, no. 17 , p. 6607.

https://doi.org/10.1021/es048667z

Harding, K.M., Gowland, J.A., and Dillon, P.J., Mercury concentration in black flies Simulium spp. (Diptera, Simuli- idae) from soft-water streams in Ontario, Canada, Environ. Pollut., 2006, vol. 143, p. 529.

https://doi.org/10.1016/j.envpol.2005.11.040

Hsu-Kim, H. and Sedlak, D.L., Similarities between inorganic sulfide and the strong $\mathrm{Hg}$ (II)-complexing ligands in municipal wastewater effluent, Environ. Sci. Technol., 2005, vol. 39, no. 11 , p. 4035 .

https://doi.org/10.1021/es050013

Hsu-Kim, H., Eckley, C.S., Achá, D., et al., Challenges and opportunities for managing quatic mercury pollution in altered landscapes, Ambio, 2018, vol. 47, p. 141.

https://doi.org/10.1007/s13280-017-1006-7

Jackson, A.K., Eagles-Smith, C.A., and Emery, C., Spatial variation in aquatic invertebrate and riparian songbird mercury exposure across a river-reservoir system with a legacy of mercury contamination, Ecotoxicology, 2019, vol. 29, no. 200 , p. 1 .

https://doi.org/10.1007/s10646-019-02043-z

Jain, C.K., Malik, D.S., and Rashmi Yadav, Metal fractionation study on bed sediments of Lake Nainital, Uttaranchal, India, Environ. Monit. Assess., 2007, vol. 130, p. 129.

https://doi.org/10.1007/s10661-006-9383-6

Jensen, P.D., Sorensen, M.A., Walton, W.E., and Trumble, J.T., Lethal and sublethal responses of an aquatic insect Culex quinquefasciatus (Diptera: Culicidae) challenged with individual and joint exposure to dissolved sodium selenate and methylmercury chloride, Environ. Toxicol., 2007, vol. 22 , p. 287.

https://doi.org/10.1002/tox.20254

Karimi, R., Chen, C.Y., and Folt, C.L., Comparing nearshore benthic and pelagic prey as mercury sources to lake fish: the importance of prey quality and mercury content, Sci. Total Environ., vol. 565, p. 211.

https://doi.org/10.1016/j.scitotenv.2016.04.162

Kocman, D., Kanduc, T., Ogrinc, N., and Horvat, M., Distribution and partitioning of mercury in a river catchment impacted by former mercury mining activity, Biogeochemistry, 2011, vol. 104, p. 183.

https://doi.org/10.1007/s10533-010-9495-5

Kolka, R.K., Sebestyen, S.D., Verry, E.S., and Brooks, K.N., Peatland Biogeochemistry and Watershed Hydrology at the Marcell Experimental Forest, Florida, USA, Boca Raton: CRC, 2011.

Komov, V.T., Gremyachikh, V.A., Kamshilova, T.B., and Lobus, N.V., The content of mercury in the muscles of perch from the lakes of the Polisto-Lovatskii raised bog massif, Tr. Gos. Prir. Zapov. Rdeiskii, 2009, no. 1, p. 102.

Komov, V.T., Pronin, N.M., and Mendsaikhan, B., The content of mercury in the muscles of fish of the Selenga River and lakes of its basin (Russia), Inland Water Biol., 2014, vol. 7, no. 2, p. 178.

https://doi.org/10.1134/S1995082914020059

Lavoie, R.A., Jardine, T.D., Chumchal, M.M., et al., Biomagnification of mercury in aquatic food webs: a worldwide meta-analysis, Environ. Sci. Technol., 2013, vol. 47, p. 13385.

https://doi.org/10.1021/es403103t

Leonova, G.A., Kolmychkov, G.V., Geletii, F.G., and Andrulaitis, L.D., Content and distribution of mercury in abiotic and biotic components of the Bratsk Reservoir ecosystem, Biol. Vnutr. Vod, 2006, no. 2, p. 97.

Medvedev, I.V. and Komov, V.T., Regeneration of freshwater planarians Dugesia tigrina and Polycelis tenuis under the influence of methyl mercury compounds of natural origin, Russ. J. Dev. Biol., 2005, vol. T. 36, no. 1, p. 29. 
Mel'nikova, T.N. and Komlev, A.M., Vodonosnost' rek Severo-Zapadnogo Kavkaza (Water Content of the Rivers of the North-West Caucasus), Maikop: Kachestvo, 2003.

Monakov, A.V., Feeding of Freshwater Invertebrates, Ghent: Kenobi Productions, 2003.

Nevado, J.J.B., Martín-Doimeadios, R.C.R., Bernardo, F.J.G., et al., Mercury in the Tapajós River basin, Brazilian Amazon: a review, Environ. Int., 2010, p. 593.

https://doi.org/10.1016/j.envint.2010.03.011

Obrist, D., Kirk, J.L., Zhang, L., et al., A review of global environmental mercury processes in response to human and natural perturbations: changes of emissions, climate, and land use, Ambio, 2018, vol. 47, p. 116.

https://doi.org/10.1007/s13280-017-1004-9

Pekov, I.V., Levitskii, V.V., and Krivovichev, V.G., Mineralogy of the Belorechenskoe field (North Caucasus, Russia), Belorechensk. Mestorozhd. Mineral. Al'm., 2010, vol. 15, no. 2, p. 17.

Polito, M.J., Brasso, R.L., Trivelpiece, W.Z., et al., Differing foraging strategies influence mercury $(\mathrm{Hg})$ exposure in an Antarctic penguin community, Environ. Pollut., 2016, vol. 218 , p. 196.

https://doi.org/10.1016/j.envpol.2016.04.097

Rodrigues, A.C.M., Jesus, F.T., Fernandes, M.A.F., et al., Mercury toxicity to freshwater organisms: extrapolation using species sensitivity distribution, Bull. Environ. Contam. Toxicol., 2013, vol. 91, p. 191.

https://doi.org/10.1007/s00128-013-1029-0

Ross, H.H., Ross, C.A., and Ross, J.R.P., A Textbook of Entomology, New York: Wiley, 1982.

Saukov, A.A., Geokhimiya (Geochemistry), Moscow: Nauka, 1975.

Scheuhammer, A.M., Meyer, M.W., Sandheinrich, M.B., and Murray, M.W., Effects of environmental methylmercury on the health of wild birds, mammals, and fish, Ambio, 2007, vol. 36, p. 12.

https://doi.org/10.1579/0044-7447(2007)36[12:EOEMOT]2.0.CO;2

Schuster, P.F., Shanley, J.B., Marvin-Dipasquale, M., et al., Mercury and organic carbon dynamics during runoff episodes from a northeastern USA watershed, Water Air Soil Pollut., 2008, vol. 187, p. 89.

https://doi.org/10.1007/s11270-007-9500-3

Shapovalov, M.I., Insects in zoobenthos communities of mountain rivers of the North-West Caucasus, in Sbornik materialov VI Mezhdunarodnoi nauchnoi konferentsii "Vulkanizm, biosfera i ekologicheskie problemy" (Proc. VI Int. Sci. Conf. "Volcanism, Biosphere, and Environmental Problems"), Maikop: Adygeisk. Gos. Univ., 2011, p. 296.

Shapovalov, M.I., Aquatic and amphibiotic insects (Plecoptera, Ephemeroptera, Trichoptera, Odonata, Coleoptera, Heteroptera) of the Northwestern Caucasus: fauna, ecology, and bioresource potential, Extended Abstract of Doctoral (Biol.) Dissertation, Vladikavkaz, 2020.

Sokal, R.R. and Rohlf, F.J., Biometry: the Principals and Practice of Statistics in Biological Research, New York: Freeman, 1995.

Speir, S.L., Chumchal, M.M., Drenner, R.W., et al., Methyl mercury and stable isotopes of nitrogen reveal that a terrestrial spider has a diet of emergent aquatic insects, $E n$ viron. Toxicol. Chem., 2014, vol. 33, p. 2506.

https://doi.org/10.1002/etc.2700
Stepanova, I.K. and Komov, V.T., Mercury accumulation in fish from water bodies of the Vologodskaya oblast, Russ. J. Ecol., 1997, vol. 28, no. 4, p. 260.

Tatsii, Y.G., Udachin, V.N., and Aminov, P.G., Environmental geochemistry of mercury in the area of emissions of the Karabashmed Copper Smelter, Geochem. Int., 2017, vol. 55 , no. 10, p. 935.

https://doi.org/10.1134/S0016702917100093

Tavshunsky, I., Eggert, S.L., and Mitchell, C.P.J., Accumulation of methylmercury in invertebrates and masked shrews (Sorex cinereus) at an upland forest-peatland interface in Northern Minnesota, USA, Bull. Environ. Contam. Toxicol., 2017, vol. 99, no. 6, p. 673.

https://doi.org/10.1007/s00128-017-2198-z

Tomilina, I.I. and Grebenjuk, L.P., Induction of deformities of the hard-chitinized mouthpart structures of larvae Chironomus riparius Meigen under various contents of persistent organic substances in bottom sediments, Inland $\mathrm{Wa}$ ter Biol., 2019, vol. 12, no. 3, p. 346.

https://doi.org/10.1134/S1995082919030167

Topashka-Ancheva, M., Metcheva, R., and Teodorova, S., A comparative analysis of the heavy metal loading of small mammals in different regions of Bulgaria II: Chromosomal aberrations and blood pathology, Ecotoxicol. Environ. Saf., 2003, vol. 54, p. 188.

https://doi.org/10.1016/S0147-6513(02)00052-0

Troitskii, S.K. and Tsunikova, E.P., Ryby basseinov Nizhnego Dona i Kubani: rukovodstvo po opredeleniyu vidov (Fishes of the Lower Don and Kuban Basins: Species Identification Guide), Rostov-on-Don: Knizhn. Izd., 1988.

Tweedy, B.N., Drenner, R.W., Chumchal, M.M., and Kennedy, J.H., Effects of fish on emergent insect-mediated flux of methyl mercury across a gradient of contamination, Environ. Sci. Technol., 2013, vol. 47, p. 1614.

https://doi.org/10.1021/es303330m

Ullrich, S.M., Ilyushchenko, M.A., Kamberov, I.M., and Tanton, T.W., Mercury contamination in the vicinity of a derelict chlor-alkali plant. part i: sediment and water contamination of Lake Balkyldak and the River Irtysh, Sci. Total Environ., 2007, vol. 381, nos. 1-3.

https://doi.org/10.1016/j.scitotenv.2007.02.033

Vasil'ev, O.F. and Sukhenko, S.A., Ecology and hydraulic engineering ecological risk in creating the Katun Reservoir in connection with the presence of mercury anomalies on the drainage basin area, Hydrotech. Constr., 1993, vol. 27, no. 10 , p. 563 .

https://doi.org/10.1007/BF01545063

Volkodav, I.G., Noble metals in ores and placers of Adygea, Vestn. Adygeisk. Gos. Univ., Ser. 4: Estestv.-Mat. Tekhn. Nauki, 2012, no. 4 (110), p. 163.

Williams, E.B., Chumchal, M.M., Drenner, R.W., and Kennedy, J.H., Seasonality of odonate-mediated methylmercury flux from permanent and semipermanent ponds and potential risk to red-winged blackbirds (Agelaius phoeniceus), Environ. Toxicol. Chem., 2017, vol. 36, no. 10, p. 2833.

https://doi.org/10.1002/etc.3844

de Wit, H.A., Kainz, M.J., and Lindholm, M., Methylmercury bioaccumulation in invertebrates of boreal streams in Norway: effects of aqueous methylmercury and diet retention, Environ. Pollut., 2012, vol. 164, p. 235.

https://doi.org/10.1016/j.envpol.2012.01.041

Translated by D. Pavlov 